Hub-Periphery Development

Pattern and Inclusive Growth:

Case Study of Guangdong Province

XUBEI LUO

NONG ZHU

2019S-39 CAHIER SCIENTIFIQUE 
2019s-39

Hub-Periphery Development Pattern and Inclusive Growth: Case Study of Guangdong Province

Xubei Luo, Nong Zhu

\section{Série Scientifique \\ Scientific Series}

Montréal

Décembre/December 2019

(C) 2019 Xubei Luo, Nong Zhu. Tous droits réservés. All rights reserved. Reproduction partielle permise avec citation du document source, incluant la notice $($ C. Short sections may be quoted without explicit permission, if full credit, including (C) notice, is given to the source.

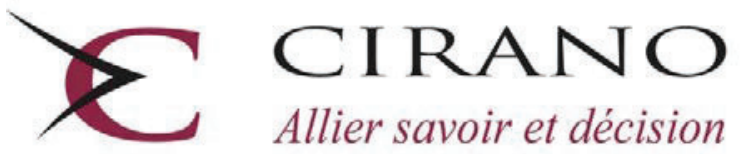

Centre interuniversitaire de recherche en analyse des organisations 


\section{CIRANO}

Le CIRANO est un organisme sans but lucratif constitué en vertu de la Loi des compagnies du Québec. Le financement de son infrastructure et de ses activités de recherche provient des cotisations de ses organisations-membres, d'une subvention d'infrastructure du gouvernement du Québec, de même que des subventions et mandats obtenus par ses équipes de recherche.

CIRANO is a private non-profit organization incorporated under the Quebec Companies Act. Its infrastructure and research activities are funded through fees paid by member organizations, an infrastructure grant from the government of Quebec, and grants and research mandates obtained by its research teams.

\section{Les partenaires du CIRANO}

\section{Partenaires corporatifs}

Autorité des marchés financiers

Banque de développement du Canada

Banque du Canada

Banque Laurentienne

Banque Nationale du Canada

Bell Canada

BMO Groupe financier

Caisse de dépôt et placement du Québec

Canada Manuvie

Énergir

Hydro-Québec

Innovation, Sciences et Développement économique Canada

Intact Corporation Financière

Investissements PSP

Ministère de l'Économie, de la Science et de l'Innovation

Ministère des Finances du Québec

Mouvement Desjardins

Power Corporation du Canada

Rio Tinto

Ville de Montréal

\section{Partenaires universitaires}

École de technologie supérieure

École nationale d'administration publique

HEC Montréal

Institut national de la recherche scientifique

Polytechnique Montréal

Université Concordia

Université de Montréal

Université de Sherbrooke

Université du Québec

Université du Québec à Montréal

Université Laval

Université McGill

Le CIRANO collabore avec de nombreux centres et chaires de recherche universitaires dont on peut consulter la liste sur son site web.

Les cahiers de la série scientifique (CS) visent à rendre accessibles des résultats de recherche effectuée au CIRANO afin de susciter échanges et commentaires. Ces cahiers sont écrits dans le style des publications scientifiques. Les idées et les opinions émises sont sous l'unique responsabilité des auteurs et ne représentent pas nécessairement les positions du CIRANO ou de ses partenaires.

This paper presents research carried out at CIRANO and aims at encouraging discussion and comment. The observations and viewpoints expressed are the sole responsibility of the authors. They do not necessarily represent positions of CIRANO or its partners. 


\title{
Hub-Periphery Development Pattern and Inclusive Growth: Case Study of Guangdong Province *
}

\author{
Xubei Luo ${ }^{\dagger}$, Nong Zhu ${ }^{\ddagger}$
}

\begin{abstract}
Résumé
The hub-periphery development pattern of the Guangdong economy, to some extent, is a miniature of that of the Chinese economy. The Pearl River Delta, drawing from its first-nature comparative advantages in factor endowments and proximity to Hong Kong SAR, China, and Macau SAR, China, and the second-nature advantages as first-movers in the reforms in attracting and retaining domestic and foreign resources, has developed into a regional economic center. This paper examines the pattern of inter- and intra-provincial migration and that of the concentration of production, to explore the challenges and opportunities for the success of "double transfer." The paper suggests a four-prong approach, to improve the business environment, support the realization of latent comparative advantages, increase the skill level of the labor force to support the upgrade of the production structure, and protect the vulnerable, to support the inclusive growth of the economy in Guangdong in a sustainable manner.
\end{abstract}

Keywords/Mots-clés: Migration, Chine

JEL Codes/Codes JEL: J61, O11, R12

\footnotetext{
* The authors would like to thank Ehtisham Ahmad, Ahmad Ahsan, Shahrokh Fardoust, Chorching Goh, Sanjeev Gupta, Khalid Ikram, John Litwack, Teresa Ter-Minassian, Meili Niu, Kezhou Xiao, Chunlin Zhang, and participants at the conference of Financing Local Investments within a Sustainable Development Strategy for P.R. China (organized by Asia Research Center, London School of Economics \& Sun Yat-Sen University, January, 2015) for valuable comments.

${ }^{\dagger}$ The World Bank

${ }^{\ddagger}$ INRS-UCS, University of Quebec
} 


\section{Introduction}

Since the late 1970s, institutional and economic reforms have played a crucial role in the unprecedented development of the Chinese economy. The reforms have provided the basis for the transition to market economy and facilitated the integration of the domestic market with the international market. The interdependence of institutional reforms and opening up policies strengthened each other. Through incrementally reforming the centrally planned system to improve incentives and increase the scope of the market in resource allocation, and through building new institutions to support a market system before old institutions were destroyed, China's transition has achieved a remarkable success (Boublil, 1997; Démurger, 1997; Qian, 2003; Wilmots, 1997). Thanks to the advantageous factor endowment and favorable policy inclination, the coastal region soon took off. Export-oriented and globalized industries are largely concentrated in the coastal region and low tech and resource based industries are mainly located in the inland region. Disparities within the province increased as the economy rapidly developed. The dynamics of the coastal provinces and the relative stagnation of the inland provinces configure a center-periphery regional growth structure (Lu, 2008; Naughton, 1999; Chen and Fleisher, 1996).

Guangdong province, once an economic backwater, is a pioneer in the process of reforms and opening up (ElSayed et al., 2006). ${ }^{1}$ The economy of Guangdong is export-oriented, and largely supported by inflow of foreign direct investment (FDI), of which a significant share is from Hong Kong SAR, China and Macau SAR, China to the Pearl River Delta (PRD), and migrant labor. The province hosts three of the four Special Economic Zones established in the early 1980s (Shenzhen, Zhuhai, and Shantou, along with Xiamen in Fujian province). The special tax policies and financial incentives provided to the Special Economic Zones have stimulated the development of the foreign and domestic private companies and changed the structure of the economy. The development of the economy of Guangdong (particularly PRD) started with a "three-plus-one" trading mix (custom manufacturing with materials, designs or samples supplied and compensation trade) and developed to diverse ownership. The large inflow of FDI created strong demand for migrant labor.

The long-term development of the economy of Guangdong is conditioned by the sustainable upgrade of the industrial structure and that of job creation to attract and retain the needed skills as well as provide workers (including migrant workers) adequate access to social services of good quality. In recent years, partly related to the global crisis, the slowdown of the GDP growth rate and the decline of net inflow of migrant workers, reflected as an emerging shortage of migrant workers (MingGongHuang), in some cities in Guangdong, led to the hot debate of whether the development pattern of Guangdong has reached a turning point (Liang and $\mathrm{Wu}$, 2003; Meng et al., 2007; Wang and Fan, 2006; Zhu and Wang, 2006).

The objectives of this paper are to present a comprehensive picture of the hub-periphery development pattern of the economy in Guangdong as a miniature of that of China and examine the opportunities and challenges for sustainable inclusive growth. It focuses on areas that merit particular policy consideration in supporting the continuous upgrade of the economic structure through "double transfer" - transfer industries from the PRD to the rest of the provinces; and

\footnotetext{
${ }^{1}$ The open-door policy began with the establishment of the first special economic zones (SEZs) in 1980 in three cities (Shenzhen, Zhuhai and Shantou) in Guangdong province and one city (Xiamen) in Fujian province, then the preferential status of the SEZs soon rolled out to 14 other coastal cities in 1984, to the three deltas in 1985, to Hainan in 1988, to Pudong in Shanghai in 1990, and then gradually to 11 border cities and eventually to all capitals of the inland provinces and autonomous regions during the 1990s.
} 
transfer labor in the lagging regions from the primary sector to the secondary and tertiary sectors, including transfer of high-skilled labor to the PRD.

The paper is structured as follows: The next section focuses on the hub-periphery development pattern between the PRD and the rest of the economy. Section 3 highlights the large concentration of FDI using statistics from the China Statistical Yearbooks. Section 4 examines the massive inflow of migrant workers in the province, with a focus on the unique composition of the migrant labor force in different cities drawing from the 5th and the 6th national population census data. Section 5 examines the industrial specialization and spatial concentration of the capital-, labor-, and resource-intensive industries in the province. Section 6 discusses, in the context of "double transfer", the challenges and opportunities facing the economy and presents a four-prong approach to support inclusive growth in a sustainable manner.

\section{Hub-periphery development pattern}

The development pattern of Guangdong, to a certain extent, is a miniature of that of China. Guangdong province has witnessed rapid development since the reforms. Its average growth rate has been higher than the "four Asian dragons" during the periods when they took off. Since 1989, Guangdong has topped the total GDP rankings among all provincial-level divisions. In 2013, the province's GDP reached 6.2 trillion RMB (or 1 trillion USD) and accounted for $11 \%$ of China's GDP. Guangdong is also the largest exporter and importer in China. Its foreign trade accounted for about $28 \%$ of the country and the actual use of foreign investment accounted for about $22 \%$ of the country's total; both rank first of all the provinces. In addition, Guangdong's many major economic indicators, including total fixed assets investment, total retail sales, savings deposits of residents, per capita disposable income of urban and rural residents, and local revenues, and non-income welfare indicators, such as life expectancy, education, and health services, both rank high (see annex 1 for additional statistics of Guangdong).

The Pearl River Delta, drawing from its first-nature comparative advantages in factor endowments and proximity to Hong Kong SAR, China and Macau SAR, China, and the secondnature advantages as first-movers in the reforms in attracting and retaining domestic and foreign resources, has developed into a regional economic center and well-known world factory, with many highly specialized towns and cities (Tuan and Ng, 2004). ${ }^{2}$ Its regional GDP exceeded that of Singapore in 1998, Hong Kong SAR, China in 2003, and Taiwan, China, in 2007 (National Development and Reform Commission, 2008).

The economy is highly concentrated: the Pearl River Delta produces $80 \%$ of the regional GDP and over $95 \%$ of the exports and imports, attracts over $90 \%$ of the foreign direct investment, and hosts $90 \%$ of the migrant population. The development gaps within Guangdong widened between the Pearl River Delta and the rest (the Northern Mountainous Area and the East and West Wings), and within the PDR between economic hubs (Guangzhou, Shenzhen and Zhuhai) and the other seven cities. We illustrate this regional development gap in 2000-2013 in the following three figures: the Kernel distribution of the real GDP per capita (figure 1); Gini coefficient (figure 2), and growth incidence curve (figure 3).

\footnotetext{
${ }^{2}$ The Pearl River Delta region, including Guangzhou, Shenzhen, Zhuhai, Foshan, Huizhou, Zhongshan, Jiangmen, Shunde, and Zhaoqing, has been the pioneer since the opening-up.
} 
Figure 1: Distribution of real GDP per capita of prefecture-level cities in Guangdong (2000-

2013)

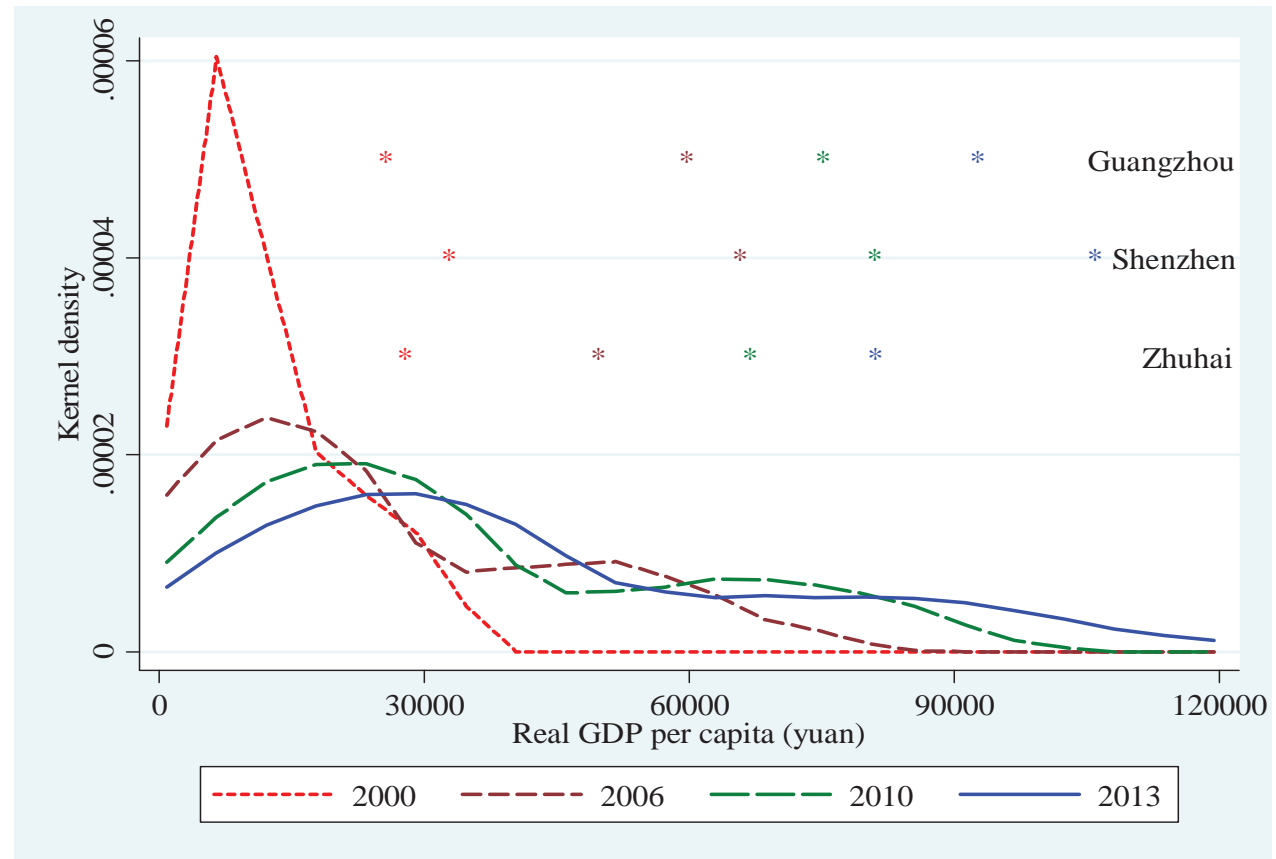

Data source: Guangdong Bureau of Statistics, Guangdong Statistical Yearbooks (several editions), China Statistical Publishing House, Beijing.

Note: The three rows of stars show the levels of real GDP per capita of Guangzhou, Shenzhen, and Zhuhai respectively, from top to bottom, with the color indicating the years of 2000 (red), 2006 (purple), 2010 (black) and 2013 (blue).

Figure 1 shows that Shenzhen, Guangzhou, and (to a lesser extent) Zhuhai are more developed than the rest of the economy in a significant manner. Figure 2 shows the Gini coefficient of the gross regional product per capita in the 21 prefecture-level cities rose from 0.35 in 2000 to almost 0.40 in 2005-2006 before steadily declining to 0.34 in the recent three years. Figure 3 shows, during the period of relatively slow growth after the Asian financial crisis in 2000-2003, the richer cities grew faster and inequality increased; during the period of high growth performance in 2003-2009, still the richer cities grew faster and inequality continued to increase; while in the recent period of 2009-2013, when growth slowed down (partly related to the global economic crisis and the restructuring), the poorer cities grew faster than the richer ones and inequality started to decline. 
Figure 2: Gini index of real GDP per capita of prefecture-level cities in Guangdong (2000-2013)

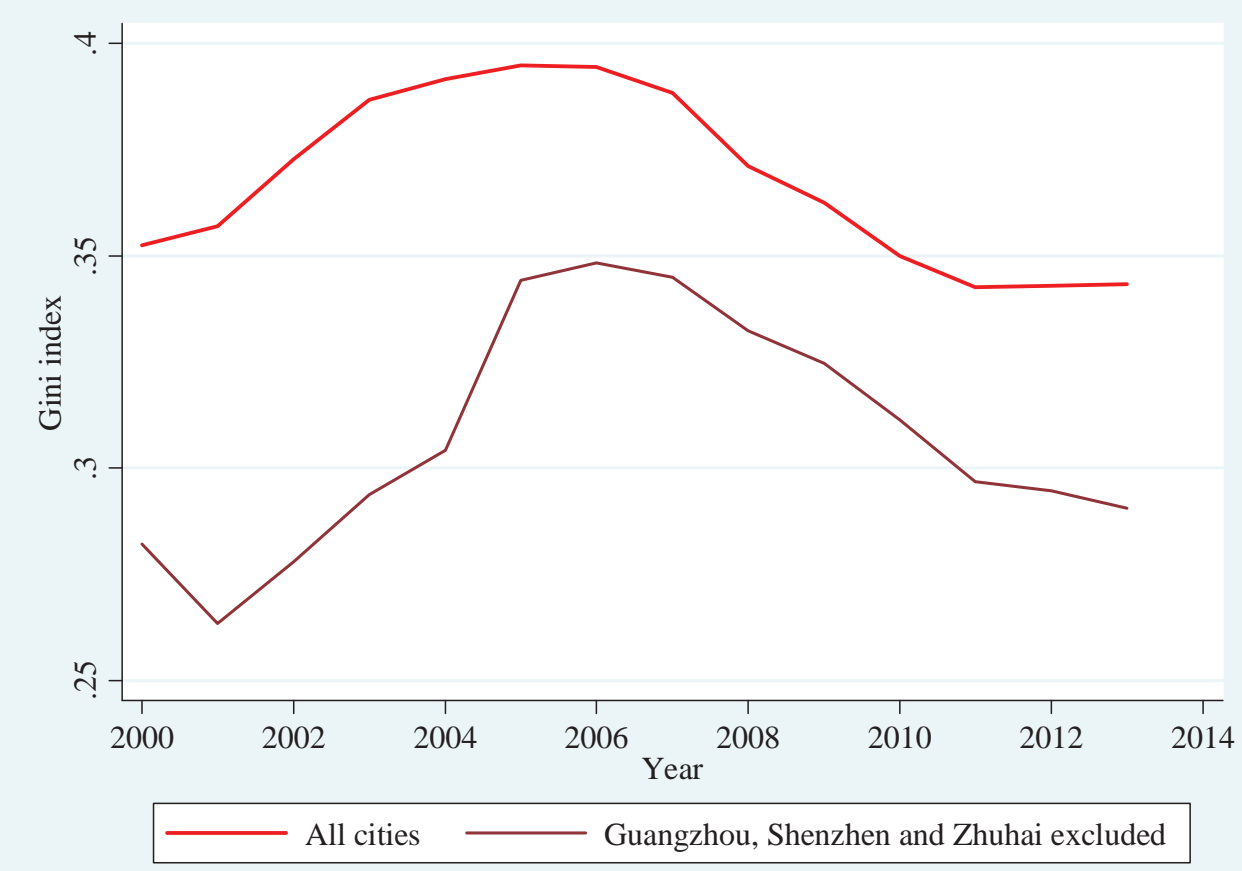

Data source: Guangdong Bureau of Statistics, 2014.

Figure 3: Growth Incidence Curve

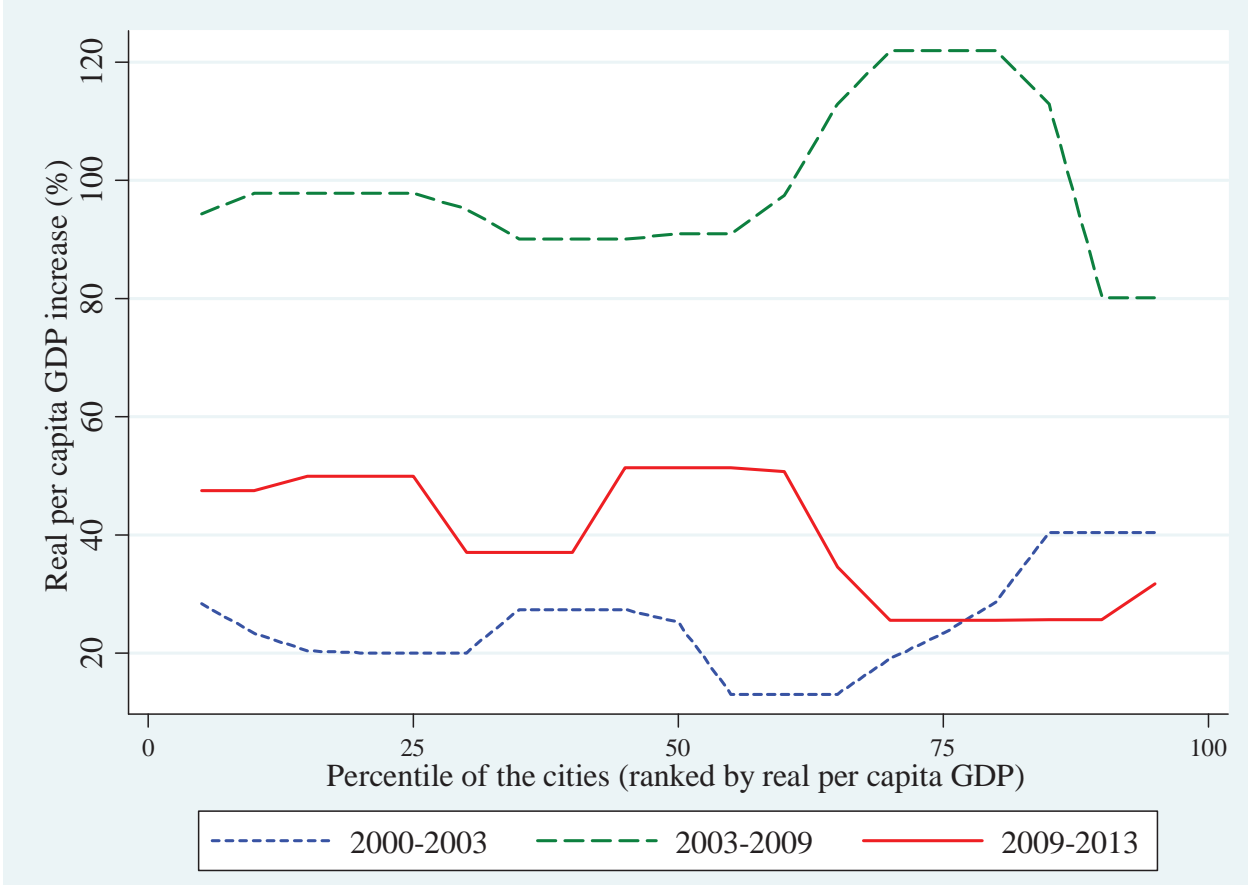

Data source: Guangdong Bureau of Statistics, 2014.

Note: The growth incidence curves are created with "smooth" function for readability. 


\section{Intra- and inter-provincial labor migration}

Worldwide, labor migration is a powerful tool to reduce distance to economic opportunity. Eight million Americans change states every year (World Bank, 2008). In China, the gradual reform of the Household Registration System (Hukou) reduced the constraint on domestic labor mobility (Chan and Li, 1999; Chen and Wu, 2005; Fan, 2005a; 2005b; He and Pooler, 2002; Li, 2004; Liang, 2001; Shen, 1999; Zhang and Song, 2003; Wu and Yao, 2003; Zhao, 2005). The significant inflow of capital and the development of an export-oriented economy in the coastal provinces created strong demand for labor (Li, 1997; Wong et al., 2003; Zhu, 2000). The large-scale migration from rural areas and inland regions to urban areas and coastal regions provided coastal and urban areas with a flexible labor supply at reasonable costs and contributed to the rapid development of their labor intensive industries (Luo and Zhu, 2008). This in turn accelerated the formation and expansion of the small and medium size cities in the coastal provinces and increased the potential for the exploitation of economies of scale (Sit and Yang, 1997; Li, 1997).

A similar story applies for Guangdong, with PRD (especially Guangzhou, Shenzhen, and Zhuhai) as the hubs. The inflow of migrant workers largely contributed to the rapid development of Guangdong. Guangdong officially became the most populous province in 2005. Its total population hit 110 million then, with 79 million registered permanent residents and 31 million migrants who have lived in Guangdong for more than six months. ${ }^{3}$ The PRD, the Yangtze River Delta, and Bohai Bay area, are the three largest regions with significant migrant concentrations in China (Trudel, 2008).

The Chinese fifth census data shows, in 2005, that of the 93 million working age cross-country migrants, some two-thirds are urban labor and some one-third rural labor. Urban areas are the major destination of migration: roughly 67 million moved to urban areas and 26 million to rural areas. The scale of intra-provincial migration was higher than that of inter-provincial migration. At the national level, the average intra-provincial immigration rate is about $11.8 \%$, and interprovincial immigration rate $6.4 \%$. In Guangdong, in 1978-2013, the average total migration rate is $2.8 \%$, and the average net migration rate is $0.3 \%$. The net migration rate is positive in most of the years. It gradually increased since 1978, peaked around 2006, and fluctuated downward in the recent years. The average gross inflow of migrants amounted to some 1.06 million per year. With an average outflow of migrants of some 0.84 million, this results in a net inflow of migrants of 0.22 million (see figure 4). This "demographic dividend" has played a significant role in contributing to the economic development in Guangdong.

\footnotetext{
${ }^{3}$ http://www.chinadaily.com.cn/english/doc/2005-01/29/content_413299.htm.
} 
Figure 4: Labor inflow and outflow in Guangdong (1978-2013)

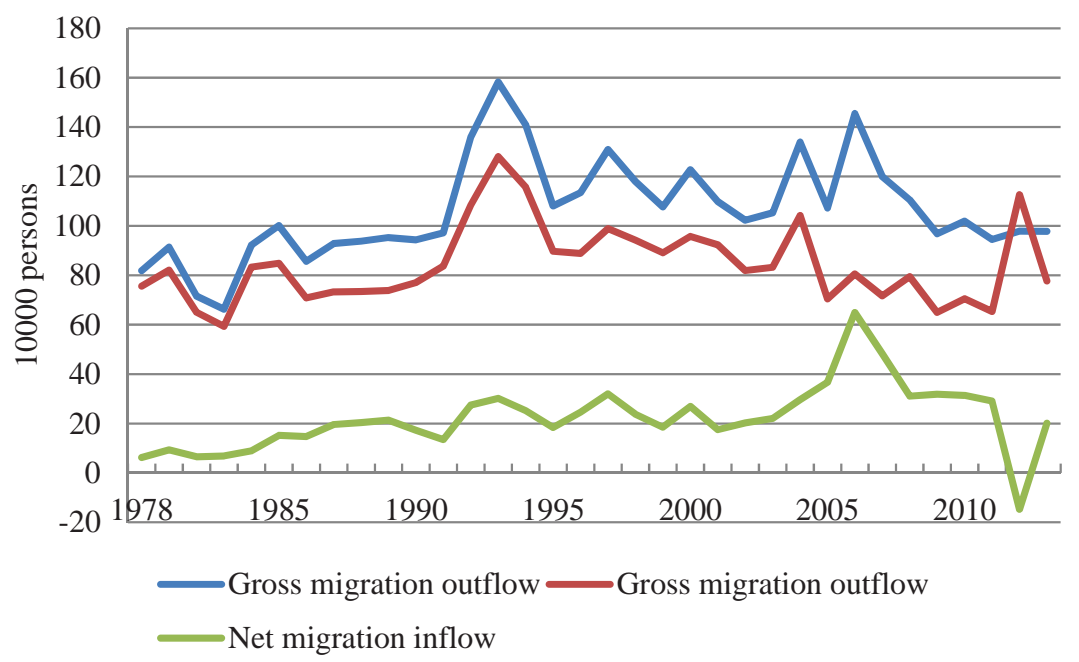

Data Source: Guangdong Bureau of Statistics, 2014.

The distribution of inter- and intra-provincial migration differs significantly between the PRD and the rest of the province (table 1). A closer look at the fifth population census data shows that nearly 90 percent of the migrant population concentrates in the Pearl River Delta, of which $50 \%$ in Shenzhen and Guangzhou. For the entire province, the intra-provincial migration and inter-provincial migration accounted for $40 \%$ and $60 \%$ of the total migration population, respectively. However, for the Pearl River Delta, the intra-provincial and inter-provincial migration ratios are $1 / 3$ and $2 / 3$, respectively; while in other cities in the province, intraprovincial migration and inter-provincial migration accounted for $3 / 4$ and $1 / 4$, respectively. In other words, most of the inter-provincial population is concentrated in the Pearl River Delta; while for other cities, the majority of the migrant workers are from within Guangdong. The net migration inflows in Guangdong are mainly the migrants to Pearl River Delta from other provinces.

Table 1 - The distribution of migrant inflows in Guangdong

\begin{tabular}{|c|c|c|c|c|c|c|c|c|c|c|}
\hline & \multicolumn{5}{|c|}{2000} & \multicolumn{5}{|c|}{2010} \\
\hline & \multicolumn{3}{|c|}{$\begin{array}{l}\text { Number of migrant inflow } \\
\text { (10000 persons) }\end{array}$} & \multicolumn{2}{|c|}{$\begin{array}{c}\text { Percentage } \\
(\text { Total migration=100) }\end{array}$} & \multicolumn{3}{|c|}{$\begin{array}{c}\text { Number of migrant inflow } \\
\text { (10000 persons) }\end{array}$} & \multicolumn{2}{|c|}{$\begin{array}{c}\text { Percentage } \\
\text { (Total migration }=100)\end{array}$} \\
\hline & Total & $\begin{array}{c}\text { Intra- } \\
\text { provincial } \\
\text { migration }\end{array}$ & $\begin{array}{c}\text { Inter- } \\
\text { provincial } \\
\text { migration }\end{array}$ & $\begin{array}{c}\text { Intra- } \\
\text { provincial } \\
\text { migration }\end{array}$ & $\begin{array}{c}\text { Inter- } \\
\text { provincial } \\
\text { migration }\end{array}$ & Total & $\begin{array}{c}\text { Intra- } \\
\text { provincial } \\
\text { migration }\end{array}$ & $\begin{array}{c}\text { Inter- } \\
\text { provincial } \\
\text { migration }\end{array}$ & $\begin{array}{c}\text { Intra- } \\
\text { provincial } \\
\text { migration }\end{array}$ & $\begin{array}{c}\text { Inter- } \\
\text { provincial } \\
\text { migration }\end{array}$ \\
\hline $\begin{array}{l}\text { Total } \\
\text { Pearl River } \\
\text { Delta }\end{array}$ & 2530.4 & 1023.9 & 1506.5 & 40.5 & 59.5 & 3680.7 & 1530.9 & 2149.8 & 41.6 & 58.4 \\
\hline Sub-total & 2170.4 & 753 & 1417.5 & 34.7 & 65.3 & 3136.3 & 1115.5 & 2020.8 & 35.6 & 64.4 \\
\hline Guangzhou & 428.2 & 213.2 & 215 & 49.8 & 50.2 & 614.7 & 314.5 & 300.3 & 51.2 & 48.8 \\
\hline Shenzhen & 607.1 & 201.5 & 405.6 & 33.2 & 66.8 & 851.5 & 271.9 & 579.6 & 31.9 & 68.1 \\
\hline Zhuhai & 66.6 & 30.9 & 35.7 & 46.3 & 53.7 & 72.9 & 37.2 & 35.8 & 50.9 & 49.1 \\
\hline Foshan & 240.3 & 86.2 & 154.1 & 35.9 & 64.1 & 387 & 136.8 & 250.3 & 35.3 & 64.7 \\
\hline Huizhou & 111.8 & 46.6 & 65.2 & 41.7 & 58.3 & 205.8 & 88.6 & 117.2 & 43.1 & 56.9 \\
\hline Dongguan & 500.9 & 87.3 & 413.7 & 17.4 & 82.6 & 658.3 & 125.1 & 533.3 & 19 & 81 \\
\hline Zhongshan & 109.9 & 23.8 & 86.1 & 21.7 & 78.3 & 176.2 & 43.8 & 132.4 & 24.9 & 75.1 \\
\hline Jiangmen & 68.3 & 36.1 & 32.2 & 52.9 & 47.1 & 111.1 & 59.5 & 51.6 & 53.6 & 46.4 \\
\hline Zhaoqing & 37.4 & 27.4 & 10 & 73.3 & 26.7 & 58.8 & 38.2 & 20.6 & 65 & 35 \\
\hline Other cities & 360 & 271 & 89 & 75.3 & 24.7 & 544.3 & 415.4 & 129 & 76.3 & 23.7 \\
\hline
\end{tabular}


The migration patterns also vary within PRD across cities (table 1) with a sharp difference between Guangzhou and the other cities, and between PRD and the rest of the economy. In Guangzhou, an international metropolis and traditional economic center, about 50 percent of the inflow of total migrants (4.28 million) come from other parts of Guangdong Province, 50 percent come from other provinces. Shenzhen, followed by Dongguan, Foshan and Zhongshan, the dynamic export-oriented economy and emerging economic centers, the inflow of migrants are mostly from other provinces. For example, of the total inflow of migrants to Shenzhen (6.07 million) and that to Foshan (2.4 million), about one-third come from other parts of Guangdong, two-thirds from other provinces; for Dongguan and Zhongshan, respectively, out of the 5.01 million and 1.1 million total inflow of migrants, nearly 80 percent come from other provinces. While for the less developed cities, such as Zhaoqing, out of the 370,000 total inflow of migrants, some two-thirds come from other parts of the province. Non-PRD cities in Guangdong share the similar migration patterns as Zhaoqing. The ratios of intra- vs. interprovincial migration in most cities remained similar in 2000 and 2010.

The majority of the migrant workers from Guangdong chose to move to large cities, while those from other provinces largely concentrated in the PRD, particularly Shenzhen and Dongguan. As shown in figure $5,75 \%$ of the intra-provincial migrant population concentrates in the PRD, of which $20 \%$ in Guangzhou and Shenzhen each, while $95 \%$ of the intra-provincial migrant population concentrated in the PRD, of which some $28 \%$ concentrates in Dongguan, $27 \%$ in Shenzhen, $14 \%$ in Guangzhou, and $10 \%$ in Foshan, and employed in the labor-intensive industries. The pattern is similar in 2010 as in $2000 .{ }^{4}$

Figure 5: Distribution of intra- and inter-provincial migration inflows in Guangdong (2010)

2010 Intra-provincial migration

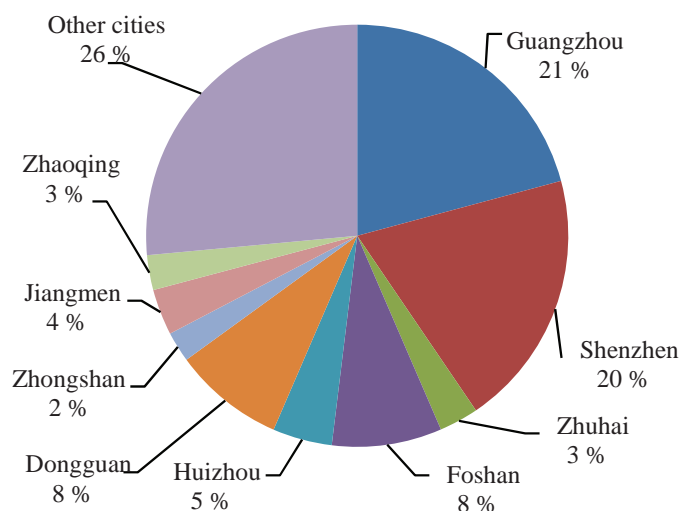

2010 Inter-provincial migration

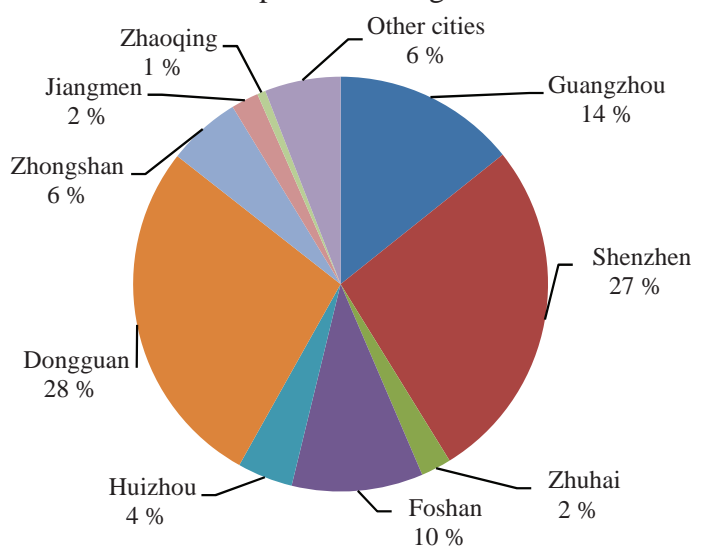

Data source: China Bureau of Statistics, 2005; Guangdong Bureau of Statistics, 2012.

\footnotetext{
${ }^{4}$ Migration data in 2000 available upon request.
} 


\section{Concentration of resource, labor and capital intensive industries}

As the economy has developed, the production structure has gradually changed in Guangdong. The ratio of the primary, secondary and tertiary industries changed from $29.8 \%$, 46.6 \%, $23.6 \%$ in 1978 , to $5.5 \%, 51.6 \%, 42.9 \%$ in 2008 , and to $4.9 \%, 47.3 \%, 47.8 \%$ in 2013 . Nine major industries are particularly competitive in the domestic market and gaining shares in the global arena, including the three major traditional industries, food and beverage, textiles, and building materials; the three major new pillar industries, electronic communications, electrical machinery, and petrochemicals; and the three emerging industries, forestry and paper, pharmaceutical, and automotive. The Pearl River Delta has become one of the world's major manufacturing bases (for example, electronic information industry), attracting investments from many multinational corporations and international consortia.

Compared with that in the Pearl River Delta, the production structure in the rest of the province, is less developed, with a significantly higher share of the primary sector and lower levels of urbanization and export-orientation. To understand the different production structure at the industry level within the province, ${ }^{5}$ we group the 43 industries listed in the Guangdong industrial economic statistical yearbooks into three large categories (called "sectors" hereafter): resource intensive sector, labor intensive sector and capital intensive sector. We measure the relative concentration of sector $i(i=1,2,3)$ in region $j$ in time $t(t=2006,2007 \ldots 2013)$ by an indicator of specialization, noted as IS, as follows:

$$
I S_{i, j, t}=\frac{v a_{i, j, t}}{\sum_{j} v a_{i, j, t}} / \frac{\sum_{i} v a_{i, j, t}}{\sum_{i} \sum_{j} v a_{i, j, t}} \quad \text { with } v a_{i, j, t}=\sum_{m_{i}} v a_{m_{i}, j, t}
$$

where $m_{i}$ stands for the number of industries that belong to sector $i$. In other words, $v a_{i, j, t}$ is the sum of the value added of all industries in the sector $i$. In a relative sense, the more specialized a region $j$ is in the sector $i$ in time $t$, the higher is the value of this indicator.

We calculate the IS in two ways (or two levels). Table 2 presents the results of $I S$ by region (grouping the 22 cities into four regions: Pearl River Delta, East Wing, West Wing, and Mountain area). ${ }^{6}$ The results show a sharp difference in the patterns of concentration of industries: capital intensive industries largely clustered in Pearl River Delta, labor intensive industries mainly located in East Wing (followed by the Northern Mountainous area), and resource intensive industries highly concentrated in the West Wing and Northern Mountainous Area. The high specialization of the capital intensive and labor intensive industries in the PRD and East Wing, respectively, reveals their comparative advantages.

\footnotetext{
${ }^{5}$ The empirical results of specialization at the industry and city levels are available upon request. For readability, we present in this paper the results of specialization of capital-, labor- and resource- intensive industries at the four regional level.

${ }^{6}$ In annex 3, we consider each of the ten cities in Pearl River Delta and consider all other cities as the rest of the province, and calculate the IS by these 12 entities.
} 
Table 2: Specialization in resource, labor and capital intensive industries in Guangdong

\begin{tabular}{|c|c|c|c|}
\hline & $\begin{array}{c}\text { Resource intensive } \\
\text { industries }\end{array}$ & $\begin{array}{c}\text { Labor intensive } \\
\text { industries }\end{array}$ & $\begin{array}{c}\text { Capital intensive } \\
\text { industries }\end{array}$ \\
\hline \multicolumn{4}{|l|}{2006} \\
\hline Pearl River Delta & 0.91 & 0.96 & 1.02 \\
\hline East & 0.89 & 1.96 & 0.71 \\
\hline West & 2.60 & 1.03 & 0.81 \\
\hline Mountain area & 2.10 & 1.20 & 0.81 \\
\hline \multicolumn{4}{|l|}{2007} \\
\hline Pearl River Delta & 0.91 & 0.95 & 1.03 \\
\hline East & 0.92 & 1.89 & 0.70 \\
\hline West & 2.70 & 1.05 & 0.80 \\
\hline Mountain area & 2.37 & 1.15 & 0.80 \\
\hline \multicolumn{4}{|l|}{2008} \\
\hline Pearl River Delta & 0.88 & 0.95 & 1.03 \\
\hline East & 0.85 & 2.03 & 0.66 \\
\hline West & 3.17 & 0.94 & 0.77 \\
\hline Mountain area & 2.77 & 1.20 & 0.72 \\
\hline \multicolumn{4}{|l|}{2009} \\
\hline Pearl River Delta & 0.86 & 0.94 & 1.03 \\
\hline East & 1.11 & 2.05 & 0.62 \\
\hline West & 3.47 & 0.97 & 0.80 \\
\hline Mountain area & 3.34 & 1.35 & 0.68 \\
\hline \multicolumn{4}{|l|}{2010} \\
\hline Pearl River Delta & 0.91 & 0.91 & 1.03 \\
\hline East & 1.10 & 2.73 & 0.54 \\
\hline West & 6.21 & 1.23 & 0.70 \\
\hline Mountain area & 5.22 & 1.27 & 0.73 \\
\hline \multicolumn{4}{|l|}{2011} \\
\hline Pearl River Delta & 0.86 & 0.91 & 1.04 \\
\hline East & 1.13 & 2.12 & 0.57 \\
\hline West & 3.09 & 1.09 & 0.78 \\
\hline Mountain area & 4.07 & 1.21 & 0.64 \\
\hline \multicolumn{4}{|l|}{2012} \\
\hline Pearl River Delta & 0.92 & 0.91 & 1.03 \\
\hline East & 1.13 & 2.62 & 0.50 \\
\hline West & 4.92 & 1.21 & 0.76 \\
\hline Mountain area & 4.36 & 1.06 & 0.83 \\
\hline \multicolumn{4}{|l|}{2013} \\
\hline Pearl River Delta & 0.83 & 0.88 & 1.07 \\
\hline East & 1.58 & 1.77 & 0.61 \\
\hline West & 1.63 & 1.08 & 0.91 \\
\hline Mountain area & 4.00 & 1.01 & 0.74 \\
\hline
\end{tabular}

Data Source: Guangdong Bureau of Statistics, 2014.

Further, to examine the extent to which the capital-, labor-, and resource-intensive industries concentrate in the four regions, we follow Wen (2004) and Amiti and Wen (2001) to calculate the Gini coefficient as follows:

$$
G_{i}=\frac{1}{2 n \times n \times S_{i}} \sum_{k=1}^{n} \sum_{j=1}^{n}\left|s_{i j-} s_{i k}\right|
$$

where $s_{i j}$ stands for the ratio of the value-added of the sector $i$ to the industrial value-added of province $j$; sik the ratio of the value-added of sector $i$ to the industrial value-added of province $k ; n$ the number of regions $(n=4)$; $s_{i}$ the average portion of the sector $i$ in comparison of the entire three sectors. If the sector $i$ is equally distributed among all regions, $G_{i}$ is equal to zero; if the sector $i$ is 
concentrated in only one region or city, the value of $G_{i}$ approaches 1 . In other words, the higher the value of $G_{i}$, the more concentrated the sector $i$.

Consistent with the results above on specialization, the capital intensive industries are slightly more concentrated spatially (mainly in PRD) than the labor intensive industries. The declining concentration of resource intensive industries is consistent with the emerging structural diversification in the West Wing and Mountain Area. ${ }^{7}$ As the resource intensive industries often locate close to the factor endowments, it is natural to observe a higher spatial concentration than the other two categories (figure 6).

\section{Figure 6: Spatial concentration of resource, labor and capital intensive industries in Guangdong}

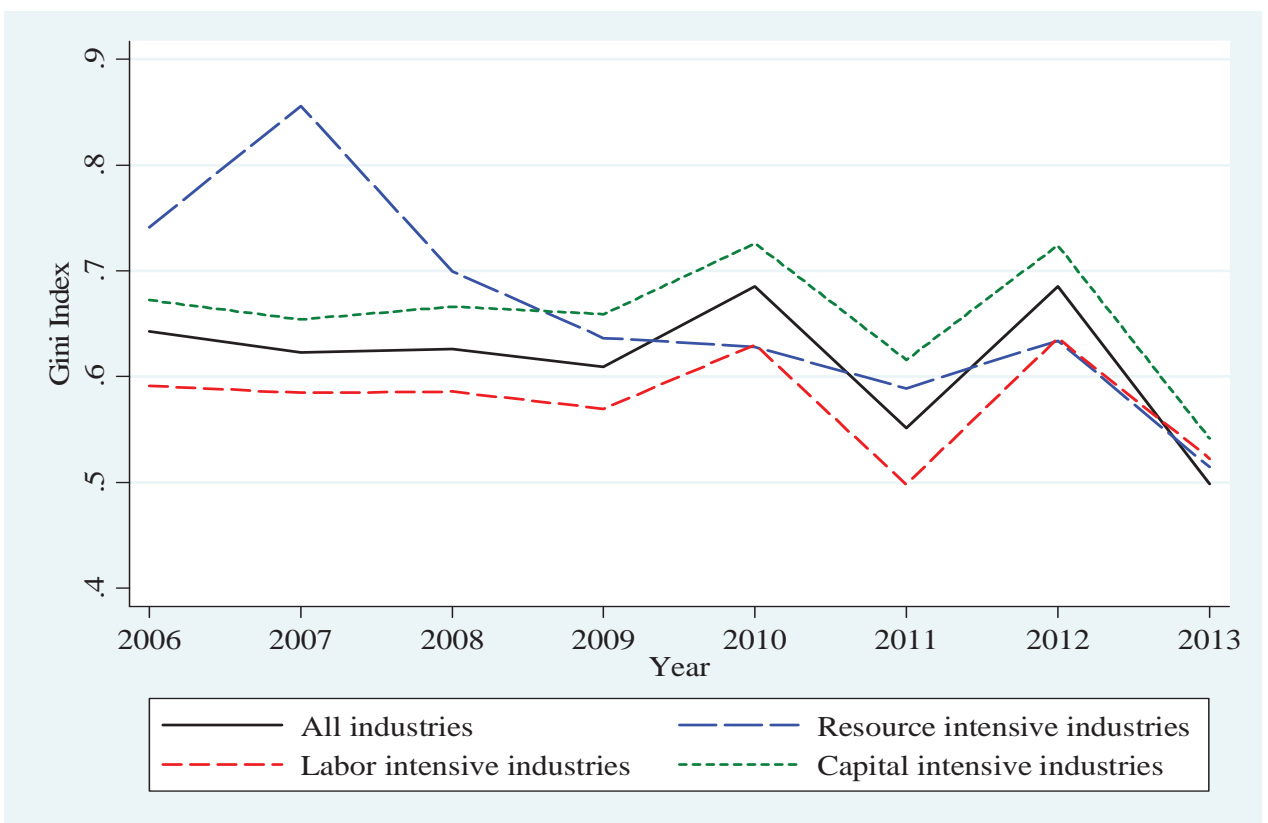

Data Source: Guangdong Bureau of Statistics, 2014.

\section{Double transfer and policy suggestions}

Since the mid-2000s, possibly compounded by the 2008 global crisis, the GDP growth in Guangdong slowed down from some $15 \%$ in the mid-2000s to some $8 \%$ in the recent years. And the net migration inflow to Guangdong declined (figure 4). While disparity (measured by Gini) within Guangdong declined (figure 2), heterogeneity of growth performance within the PRD as well as among the 21 prefecture-level cities emerged. For example, Zhaoqing (PRD), Jieyang (East Wing) and Yangjiang (West) more than doubled their GDP per capita in 2008-13 compared with average annual growth of some $10 \%$ in the province. This begs the questions of whether this showed sign of possible changes of the development pattern of the province,

\footnotetext{
${ }^{7}$ The "M-shape" fluctuation of the Gini coefficient of the capital intensive and labor intensive industries in 20092013 is of interest for further research. One possibility is related to the effects of the effects of the fiscal stimulus on the industries.
} 
what policy interventions might have contributed to the changes, and what needs to be put in place to support the inclusive development in a sustainable manner.

\subsection{Double transfers}

Since the mid-2000s, to facilitate the upgrade of the production structure and support the sustainable long-term development, the government of Guangdong and the State Council have implemented several reform and development plans (Box 1). Industrial clustering and agglomeration have significantly contributed to the improvement of the productivity and competitiveness of the Chinese economy (Fan and Scott, 2003; He and Zhu, 2009). However, associated with the rising costs of land, labor, and environment, some studies suggest the negative congestion effects start to increase and could surpass the positive effects of specialization and agglomeration. Pollution and congestion have raised additional challenges for the continuous clustering in the PRD, particularly Guangzhou and Shenzhen. The relocation of industries from the more developed regions to the less developed regions is consistent with the economic theories and development experience. Filling the infrastructure gaps and providing basic local public services are essential for the emergence of the new hubs in the less developed areas; while developing the own-source revenue basis is crucial for their sustainability.

\section{Box 1: Regional development policies in Guangdong}

In 2005, in order to promote the balanced growth of the regional economy, the Government of Guangdong Province developed special plans to stimulate the economic development of the East and West Wing areas. The plans focused on transport infrastructure, energy infrastructure, water infrastructure, industrialization and urbanization.

In 2008, the government of Guangdong province implemented the "double transfer decision" to encourage the transfer of industries from PRD to the rest of the province and the transfer of labor in the northern mountainous areas and the east and west wings from the primary sector to the secondary and tertiary sectors, including the transfer of some high-skilled labor to PRD.

In 2009 the State Council approved the "Pearl River Delta Reform and Development Plan (2008-2020)". The PRD Reform and Development Plan indicated that the Pearl River Delta region should seize the strategic opportunity of the expansion of domestic demand to invest in infrastructure and promote economic restructuring and development pattern upgrading. The Plan positioned PRD as a pioneer of further reforms, a gateway for international exchange, and a national economic center.

The main objectives of the reform and development plans are featured in the "Double transfer" - transfer industries from the Pearl River Delta to the rest of the provinces; and transfer labor in the lagging regions from the primary sector to the secondary and tertiary sectors, including transfer of high-skilled labor to the Pearl River Delta. More specifically, this means, first, strengthening the technological and innovation capacity of the PDR and phasing in the upgrading of its production structure with a focus on the advanced manufacturing sector and modern service sector to reach a GDP per capita level of 135,000 yuan by 2020 with at least $60 \%$ of value added from the service sector. Second, reducing the economic development gap between the PRD and the rest of the province and speeding up the intra-provincial relocation of industries to support the catching up of the lagging Northern mountainous areas, and the east and west wings. The latter might require the government to increase investment in the lagging regions, including investment in infrastructure and other public goods, to improve the business environment of the lagging regions and therefore their attractiveness to private capital, and to 
design and implement beneficial special policies to encourage the collaboration of the local governments of the PRD and the rest of the provinces to facilitate industry relocation.

There are signs that "double transfer" policies might have started bearing fruits. Many industrial transfer parks have been created in Guangdong and some labor intensive industries in the PRD have been transferred to the rest of the province. There also have been cases of industrial transfer from Guangdong to Jiangxi, Hunan, and Sichuan. Since the establishment of the first batch of Guangdong Industrial Transfer Park in 2005, there has been 35 provincial Industrial Transfer Parks at the end of June 2011. The establishment of the Industrial Transfer Parks contributed to the reallocation of the rural labor force. The share of additional/new rural migrant workers from within Guangdong to the PRD declined from $43.2 \%$ in 2005 to $23.1 \%$ in 2010, and that to the rest of the province increased from $56.8 \%$ to $76.9 \%{ }^{8}$ Some new towns and small cities have emerged along with the establishment of the Industrial Transfer Parks, which, if designed and managed properly, can contribute to the acceleration of urbanization.

\subsection{Policy suggestions for sustainable inclusive development}

In China, industrial clustering and agglomeration has generated significant productivity effects (He and Wang 2012). A successful transfer of industries is not about spreading the economic activities equally across geographic areas, but about facilitating the allocation and reallocation of capital and labor to the areas where they best suit the comparative advantages. To achieve a geographically more balanced development pattern efficiently and effectively, the implementation of the double transfer strategy needs to draw on the respective comparative advantages of the Pearl River Delta and the lagging periphery with a focus on the upgrading of the production structure and labor structure in both areas in an inclusive and sustainable manner.

For development to be sustainable and inclusive in Guangdong, we suggest a four-prong approach to improve the business environment, support the realization of latent comparative advantages, upgrade the skill level of labor force to support the upgrade of production structure, and protect the vulnerable (Box 2). Developing own-source revenues at the local level (including both own-source taxes and equalization transfers) and ensuring sustainable access to credit are key elements to support the emergence of the new hubs and their sustainability.

\section{Box 2 Policy suggestions for inclusive development}

First, provide an enabling business environment to support a level playing ground for all regions

- Realize the benefit of agglomeration economies through a higher density in traditional and emerging centers (develop Pearl River Delta as global economic center).

- Reduce the distance to improve regional transportation and communication infrastructure (link the lagging regions to the Pearl River Delta).

- Eliminate divisions to promote intra- and inter-provincial market integration (support the economy of Guangdong to move up the global value chain).

Second, develop special regional policy to support the realization of latent comparative advantages - Use the off-the-shelf technologies to build on the advantages of backwardness.

- Support "flying geese" / transfer of industries for the upgrade of structure.

Third, improve the skill level of the labor force to support the sustainable upgrade of production structure - Improve education and match the market demand for skills.

- Provide on-the-job training to attract and retain high quality local and migrant workers.

8 “Double Transfer in Guangdong”, NanFang Daily, 2011-09-14 
Fourth, along with the national programs, strengthen inclusive social protection to improve equal access to social services and provide targeted support to vulnerable people.

- Support the integration of migrant workers into host cities with an emphasis on the urbanization of people.

- Provide social services in an equitable manner, including formal and informal workers, the unemployed, and their families.

Global experience and the economic geography literature suggest that the most effective policies for promoting long-term growth are those that facilitate geographic concentration and economic integration, both within and across regions and countries. The path of development counts. To support the development of the economy with the existing economic center and lagging areas, government initiatives should not focus on "reducing the gaps of the productive capacity" across cities, but "moderate differences in economic welfare" between them.

The business environment in Guangdong, in particular the major cities in the Pearl River Delta, is among the best in China. Further improvement can strengthen its attractiveness to investment and spur innovation and fair competition. An enabling business environment can provide a level playing ground for all regions, hub or periphery, the needed institutions and regulations to attract and retain private investment. The sustainable development of the economy in Guangdong depends on how it can deal with the three "Ds": ${ }^{9}$ realizing the benefits of agglomeration economies through a higher density of economic activities in its major urban centers (particularly developing the PRD as global economic centers), overcoming the distance factor by making a concerted effort to improve regional transportation and communications infrastructure (linking the lagging Northern mountainous areas and the East and West Wings with the PRD), and eliminating internal and external divisions to promote intra- and interprovincial market integration and strengthen Guangdong's participation in the global economy moving up the value chain. ${ }^{10}$

Improved connectivity in a proper manner can increase efficiency and facilitate greater industrial specialization through agglomeration economies, and reduce the geographic handicap to encourage the catching-up of the lagging regions. Reduced transport costs between the northern mountainous area and the east and west wings to the PRD - and from there to overseas markets - can improve the attractiveness of the lagging regions and promote development of their firms in two ways: through lower costs of inputs delivered by these factories and through higher net revenue from sales to external markets. Greater access to both national and external markets can create more competition and reduce existing local monopolies. It can also facilitate the movement of labor, skilled and unskilled, to create greater economies of scale and rewards to innovation.

In line with the support to the establishment of Industrial Transfer Parks, facilitating the private sector actors to choose the right locations for investment with the right level of technology and capital/labor intensity can help. Special regional policy can be used in an appropriate manner to support the regions to move towards their latent comparative advantages. Improving market institutions can create and protect effective competition in the market. Measures can include addressing externality and coordination issues - such as provision of infrastructure, logistics, finance, skilled labor. The experiences of the East Asian newly industrialized economies in

\footnotetext{
${ }^{9}$ Refer to the terminology developed in the World Development Report 2009 Reshaping Economic Geography,

${ }^{10}$ See Huang and Luo (2009) for discussion at the national level.
} 
using the off-the shelf technologies to build on the advantage of backwardness and upgrade their industrial structure in the past decades are successful examples (Lin, 2012).

The government needs to promote economic integration, enhance the mobility of labor and capital, and provide targeted support to vulnerable populations. This includes developing special regional policies to encouraging complementary regional development policies that recognize and build on the uniqueness of geographic and inherited economic comparative advantages. Facilitating the relocation of industries from PRD to the less developed regions in an appropriate manner can help accelerate the process and result in mutual benefits.

As the "double transfer" policies have started bearing fruits, local governments can closely follow the comparative advantages of factor endowment of the economy to accelerate the proper upgrading of the production structures of the Pearl River Delta and the lagging regions and better match the demand and supply of labor while supporting the creation of more and better jobs in the secondary and tertiary industries. This is to include a careful consideration of the difference in the factor endowment between the Pearl River Delta and the lagging regions, and also the heterogeneity among each of the two groups. The different patterns of development in different cities discussed above illustrate the uniqueness of their advantages (or disadvantages) driven by their first or second natures.

As the economy of Guangdong, particularly the PRD, is undergoing the upgrading of structure from labor-intensive to capital-intensive or technology-intensive industries to maintain competitiveness in the global market, the demand for skilled workers increases. Provision of on-the-job training and vocational skill training can play an important role in attracting labor and enhancing their quality, which is not only important for the sustainable economic development of the province but also the inclusiveness and harmoniousness of the society.

Building the skill level of the labor force, including the local labor force and the migrant labor force, can play an increasingly crucial role in the sustainability and inclusiveness of development. Compared with the older generation of migrant workers, the younger generation of migrant workers often places higher value in the provision of training opportunities and the potential of promotion when choosing jobs. The results of a survey conducted in $2006^{11}$ showed that in the Pearl River Delta, vocational training helps to improve wages of migrant workers. To support development in a sustainable manner, the government needs to improve the skill level of the labor force to support the sustainable upgrade of production structure.

It is worth noting that, despite the deepening of reforms and improvement of labor market regulations, Hukou still plays a role in conditioning opportunities to jobs and beyond. With or without an urban household registration means significant difference in access to social services, including healthcare, education, and old-age pension. Recent studies have shown that in the urban labor market, there is discrimination against low-skilled migrant workers. Migrant workers are sometimes considered as "lower classes" in cities (Batisse and Selim, 2008; Solinger, 2004). Several studies confirm the existence of significant wage gaps between urban citizens and migrant workers with similar skills (Knight, etc., 1999; Meng and Zhang, 2001; Meng et al., 2007). A survey showed that the average income of migrant workers is only onethird of the average income of urban residents (Ministry of Labor and Social Security Research Group, 2004; Shao, 2006). Some studies suggest, after taking into account inflation, real wages of migrant workers actually declined (He, 2006). As the cost of living increased in urban areas

${ }^{11}$ See http://www.syntao.com/E_Page_Show.asp?Page_ID=6075. 
and the living standards improved in rural areas, the low level of wages hinders the willingness to migrate. The institutional fragmentation of the labor market goes beyond wage income (Hu, 2008; Lu and Song, 2005; Nielsen et al., 2007; Wu and Zhou, 1997). In fact, many unskilled migrant workers can only find jobs in the informal sector, which are often characterized by low and unstable wages along with less decent working environments (Liang, 1999; Liang and Ma, 2004; Liang and White, 1996; Day and Ma, 1994; Fan, 2002, 1999; Wang and Zuo, 1999, Guo and Iredale, 2004). Some studies (Gong, 2009; Jiang et al., 2008) suggest that related to the lack of stability of employment, migrant workers cannot stay in one place for a long time and have to move periodically or frequently.

Measures to strengthen an inclusive social protection system require improving the equal access to social services such as health care and education (and the quality of such services) and providing targeted support to the vulnerable, including migrant workers and their families. Appropriate design and implementation of the local policies, for example, provision of water and sanitation as well as health care clinics, in addition to the national policies are crucial. In an economy where the informal sector is non-negligible (the share of migrant workers who work in the informal sector is even larger), it can be a question for policy debate whether and how to use general revenue and user fees to fund such services. The potential sources of financing can include income taxes, property taxes, and value-added taxes.

\section{References}

Amiti M., Wen M., 2001. Spatial distribution of manufacturing in China. In Lloyd, P., Zhang X. (Eds), Modeling the Chinese Economy, Edward Elgar,London, 135-148.

Batisse, C., M. Sélim, 2008. Du socialisme (de marché) au post-communisme - Singularités et unicité dans la globalisation du capitalisme, Autrepart, $\mathrm{N}^{\circ} 48$.

Boublil, A., 1997. Le Siècle des chinois. Rocher, Monaco.

Chan, K.W., Z. Li, 1999. The Hukou System and Rural-Urban Migration in China: Processes and Changes. The China Quarterly, 1999, Dec. (160), 819-855.

Chen J., Fleisher B.M., 1996. Regional income inequality and economic growth in China. Journal of Comparative Economics, 22(2), 141-164.

Chen, C-H., H-L. Wu, 2005. Determinants of regional growth disparity in China's transitional economy. Journal of Economic Studies, 32(5), 406-419.

China Bureau of Statistics, 2005. China Population Census 2000. China Statistical Publishing House, Beijing.

Day, L.D., X. Ma, 1994. Migration and Urbanization in China. M.E. Sharpe, New York/London.

Démurger, S., 1997. Ouverture et croissance: le cas de la République Populaire en Chine. Thèse de doctorat, Université de Paris I, Paris, Septembre 1997.

ElSayed, A.A., R. Kulich, L. Lake, S. Megahed, 2006. The Chinese Apparel Cluster in Guangdong. Working paper, Harvard Business School May 5 $5^{\text {th }}, 2006$.

Fan, C., A. Scott, 2003. Industrial agglomeration and development: A survey of spatial economic issues in East Asia and a statistical analysis of Chinese regions. Economic Geography, 79(3), 456-469.

Fan, C.C., 1999. Migration in a Socialist Transitional Economy: Heterogeneity, Socioeconomic and Spatial Characteristics of Migrants in China and Guangdong. International Migration Review 33(4), 954-987.

Fan, C.C., 2002. The Elite, the Natives, and the Outsiders: Migration and Labor Market segmentation in Urban China. Annals of the Association of American Geographers, 92(1), 103-124. 
Fan, C.C., 2005a. Interprovincial Migration, Population Redistribution, and Regional Development in China: 1990 and 2000 Census Comparisons. The Professional Geographer, 57(2), 295-311.

Fan, C.C., 2005b. Modeling Interprovincial Migration in China, 1985-2000. Eurasian Geography and Economics, 46(3), 165-184.

Gong, S., 2009. Those uppity peasant workers: the end of the era of cheap Chinese labor. The International Economy, 23(1), 10-11.

Guangdong Bureau of Statistics, 2012. Guangdong Population Census 2010. China Statistical Publishing House, Beijing.

Guangdong Bureau of Statistics, 2014. Guangdong Statistical Yearbook 2014, China Statistical Publishing House, Beijing.

Guo, F., R. Iredale, 2004. The impact of Hukou status on migrants' employment - Findings from the 1997 Beijing migrant census. International Migration Review, 38(2), 709-731.

He, C., J. Wang, 2012. Regional and sectoral differences in the spatial restructuring of Chinese manufacturing industries during the post-WTO period. GeoJournal, 77(3), 361-381.

He, C., S. Zhu, 2009. Industrial agglomeration and labor productivity in China: an empirical study of Chinese manufacturing industries. Post Communist Economies. 21(1), 103-115.

He, G., 2006. The Shortage of Peasant Workers in the Pearl River Delta Region: An Explanation Based on Todaro Migration Model. Asian Social Science, 2(12), 41-52.

He, J., J. Pooler, 2002. The regional concentration of China's interprovincial migration flows, 1982-90. Population and Environment, 24(2), 149-182.

Hu, B., 2008. People’s mobility and Guanxi networks: A case study. China \& World Economy, 16(5), 103-117.

Huang, Y. and X. Luo, 2009. Reshaping Economic Geography in China. Reshaping Economic Geography, Edited by Yukon Huang and Alessandro Magnoli, The World Bank 2009.

Jiang, S., M. Lu, H. Sato, 2008. Happiness in the Dual Society of Urban China: Hukou Identity, Horizontal Inequality and Heterogeneous Reference. LICOS Discussion Paper Series 227/2008, Katholieke Universiteit Leuven.

Knight, J., L. Song, H. Jia, 1999. Chinese Rural Migrants in Urban Enterprises: Three Perspectives. In: S. Cook, M. Maurer-Fazio (Eds.), The Workers' State Meets the Market: Labor in China's Transition, Frank Cass, London.

Li, S., 1997. Population Migration, Regional Economic Growth and Income Determination: A Comparative Study of Dongguan and Meizhou, Chin. Urban Studies, 34(7), 999-1026.

Li, S., 2004. Population migration and urbanization in China: A comparative analysis of the 1990 population census and the 1995 national one percent sample population survey. International Migration Review, 38(2), 655-685.

Liang, Z, M. J. White, 1996. Internal Migration in China, 1950-1988. Demography, 33(3), 375384.

Liang, Z, Z. Ma, 2004. China's floating population: New evidence from the 2000 census. Population and Development Review, 30(3), 467-488.

Liang, Z., 1999. Foreign investment, economic growth, and temporary migration: the case of Shenzhen special economic zone, China. Development and Society, 28(1), 115-137.

Liang, Z., 2001. The Age of Migration in China. Population and Development Review, 27(3), 499-524.

Liang, Z., Y. Wu, 2003. Return Migration in China: New Methods and Findings. Paper Presented at the Annual Meeting of the Population Association of American, Minneapolis, MN, 2003.

Lin, J. Y., 2012. New Structural Economics: A Framework for Rethinking Development and Policy. World Bank, Washington DC. 
Lu, D., 2008. China's Regional Income Disparity: an Alternative Way to Think of the Sources and Causes. Economics of Transition, 16(1), 31-58.

Lu, Z., S. Song, 2006. Rural-urban migration and wage determination: The case of Tianjin, China. China Economy Review, 17(3), 337-345.

Luo, X., N. Zhu, 2008. Rising Income Inequality in China: A Race to the Top. Policy Research Working Paper 4700, The World Bank, Washington D. C.

Meng, X., J. Zhang, 2001. Two-tier labor markets in urban China: Occupational segregation and wage differentials between urban residents and rural migrants in Shanghai. Journal of Comparative Economics, 29(3), 485-504.

Meng, X., M. Lu, Z. Chen, 2007. The time of labor shortage has not arrived. Liberation Daily, 25 July 2007, http://www.dooland.com/newspaper/217039.

Ministry of Labor and Social Security Research Group, 2004. Survey report on the shortage of migrant workers, September 2004, http://news3.xinhuanet.com/zhengfu/200409/14/content_1979817.htm.

National Development and Reform Commission, 2008. Pearl River Delta Reform and Development Plan (2008-2020), http://politics.people.com.cn/GB/1026/8644751.html.

Naughton, B., 1999. Causes et conséquences des disparités dans la croissance économique des provinces chinoises. Revue d'Economie du Développement, 7(1-2), 33-70.

Nielsen, I., C. Nyland, R. Smyth, M. Zhang, 2007. Migration and the right to social security: Perceptions of off-farm migrants' rights to social insurance in China's Jiangsu Province. China \& World Economy, 15(2), 29-43.

Qian, Y., 2003. How Reform Worked in China?. In D. Rodrik (Ed.), In Search of Prosperity: Analytic Narratives on Economic Growth, Princeton University Press, 297- 333.

Shao, S., 2006. The end of cheap labour in China? - Implications for foreign invested firms of a new breed of 'economic man', Monash Business Review, 2(1), http://www.gsb.monash.edu.au/industry/mbr/index.html.

Shen, J., 1999. Modeling regional migration in China. Estimation and decomposition. Environment and Planning A, 31(7), 1223-1238.

Sit, V.F.S., C. Yang, 1997. Foreign-investment-induced Exo-urbanization in the Pearl River Delta. China, Urban Studies, 34(4), 647-677.

Solinger, D., 2004. The Creation of a New Underclass in China and its Implications. Rapport préparé pour le forum intitulé "POSRI International Forum on China's Development: Key Challenges for China’s Sustained Growth”, Séoul, Corée, 10-11 novembre 2004.

Trudel, M., 2008. Les déterminants de la croissance de la population urbaine en Chine. Mémoire de maîtrise, INRS-UCS, Université du Québec.

Tuan, C., L. Ng, 2004. FDI and industrial restructuring in post-WRO greater PRD: Implications on regional growth in China. The World Economy, 27(10), 1609-1630.

Wang, F., X. Zuo, 1999. Inside China's Cities: Institutional Barriers and Opportunities for Urban Migrants. The American Economic Review 89(2), 276-280.

Wang, W., C. Fan, 2006. Success or Failure: Selectivity and Reasons of Return Migration in Sichuan and Anhui, China. Environment and Planning A, 38(5), 939-958.

Wen, M., 2004, Relocation and agglomeration of Chinese industry. Journal of Development Economics, 73(1), 329-347.

Wilmots, A., 1997. La Chine économique en l'an 2000, L’Harmattan, Paris.

Wong, K., J. Shen, Z. Feng, C. Gu, 2003. An analysis of dual-track urbanisation in the Pearl River Delta since 1980. Tijdschrift Voor Economische en Sociale Geografie, 94(2), 205-218.

World Bank, 2008. World Development Report 2009: Reshaping Economic Geography, The World Bank, Washington DC.

Wu, H.X., L. Zhou, 1997. Rural-to-Urban Migration in China. Asian-Pacific Economic Literature, 10(2), 54-67. 
Wu, Z., S. Yao, 2003. Intermigration and intramigration in China: A theoretical and empirical analysis. China Economic Review, 14(4), 371-385.

Zhang, K.H., S. Song, 2003. Rural-urban migration and urbanization in China: Evidence from time-series and cross-section analyses. China Economic Review, 14(4), 386-400.

Zhao, Z., 2005. Migration, labor market flexibility, and wage determination in China: A review. Developing Economies, 43(2), 285-312.

Zhu, Y., 2000. In Situ Urbanisation in Rural China : Case Studies from Fujian Province. Development and Change, 31(2), 413-434.

Zhu, Z., H. Wang, 2006. To Foresee the Demands and Supplies of Rural Labor Forces in the Coming Years by Looking at the Phenomena of "Shortage of Farmer-Turned Workers". Statistical Research, 2006(2), 17-20. 


\section{Annex}

\section{Annex 1 Statistics of the economy of Guangdong}

The gaps between the PRD and some lagging regions seemed to tapper down in the second half of the 2000s - in 2013, but per capita GDP of the Pearl River Delta (93,114 yuan) remained significantly higher than the provincial average. In 2000, per capita GDP in the Pearl River Delta (20278 yuan) was about 3.8 times of that of the Northern Mountainous Area (5344 yuan), the 2.9 times that of the West Wing of the region (7099 yuan), and 2.8 times of that of the East Wing of the region (7294 yuan). In 2013, the regional GDP of PRD was about 3.6 times, 2.8 times and 3.4 times, respectively, that of the Northern Mountainous Area (25513 yuan), West Wing area (33712 yuan) and the east wing area (27002 yuan).

Table a1: Economic development indicators of the different regions in Guangdong in 2008 and 2013

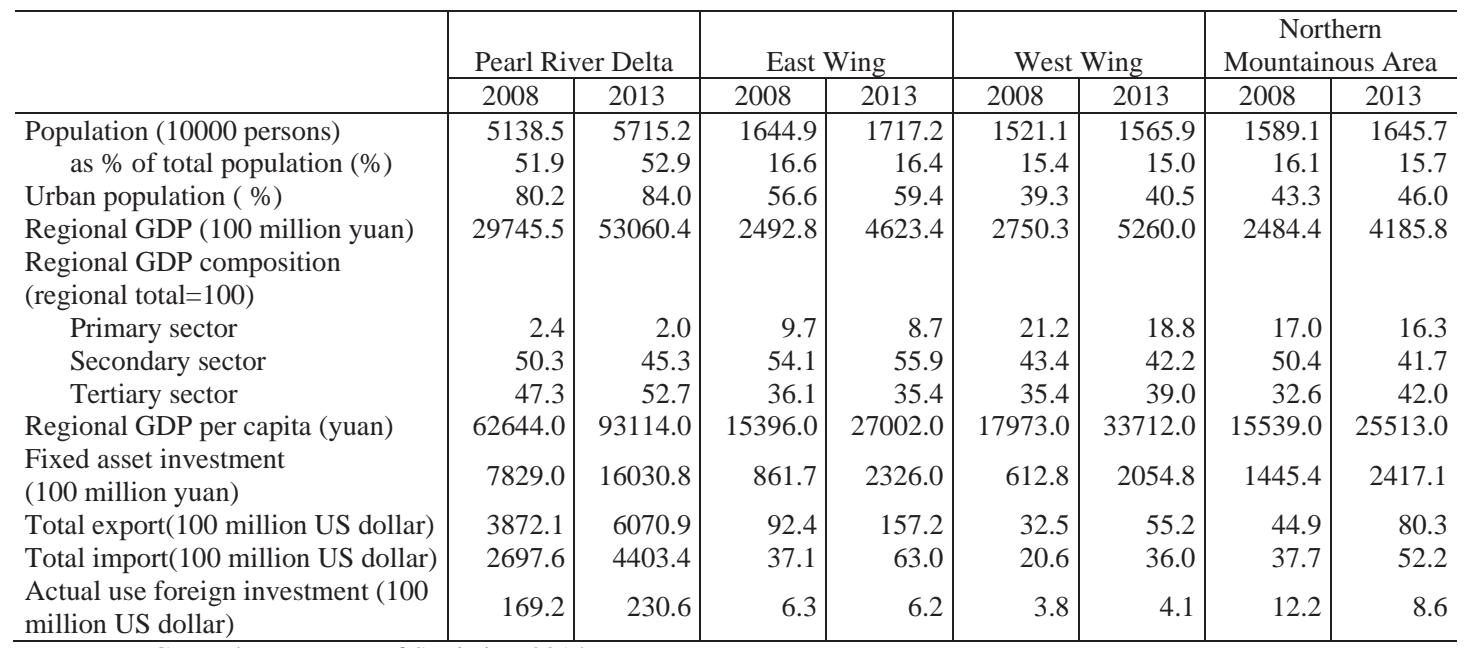

Data source: Guangdong Bureau of Statistics, 2014.

Note: Pearl River Delta includes Guangzhou, Shenzhen, Zhuhai, Foshan, Huizhou, Zhongshan, Jiangmen, Shunde, and Zhaoqing; East Wing includes Shantou, Chaozhou, Jieyang, and Shanwei; West Wing includes Zhanjiang, Maoming, and Yangjiang; and Northern Mountainous Area includes Meizhou, Heyuan, Qingyuan, Yunfu, and Chaoguan.

Table a2: The shares of regional GDP, export and import of different regions of Guangdong

\begin{tabular}{|c|c|c|c|c|c|c|c|c|c|}
\hline & \multicolumn{3}{|c|}{ Regional GDP } & \multicolumn{3}{|c|}{ Total Export } & \multicolumn{3}{|c|}{ Total Import } \\
\hline & 2000 & 2008 & 2013 & 2000 & 2008 & 2013 & 2000 & 2008 & 2013 \\
\hline Pearl River Delta & 75.2 & 79.4 & 79.0 & 92.2 & 95.8 & 95.4 & 95.0 & 96.6 & 96.7 \\
\hline East Wing & 9.5 & 6.7 & 6.9 & 4.6 & 2.3 & 2.5 & 2.8 & 1.3 & 1.4 \\
\hline West Wing & 8.5 & 7.3 & 7.8 & 2.1 & 0.8 & 0.9 & 1.4 & 0.7 & 0.8 \\
\hline Northern Mountainous Area & 6.8 & 6.6 & 6.2 & 1.1 & 1.1 & 1.3 & 0.7 & 1.4 & 1.1 \\
\hline Guangdong & 100.0 & 100.0 & 100.0 & 100.0 & 100.0 & 100.0 & 100.0 & 100.0 & 100.0 \\
\hline
\end{tabular}


Annex 2 Specialization of labor, capital and resource intensive industries in cities of the PRD and the rest of the economy in Guangdong (2006-2013)

\begin{tabular}{|c|c|c|c|}
\hline & $\begin{array}{c}\text { Resource intensive } \\
\text { industries }\end{array}$ & $\begin{array}{l}\text { Labor intensive } \\
\text { industries }\end{array}$ & $\begin{array}{c}\text { Capital intensive } \\
\text { industries }\end{array}$ \\
\hline \multicolumn{4}{|l|}{2006} \\
\hline Guangzhou & 0.22 & 1.03 & 1.08 \\
\hline Shenzhen & 1.79 & 0.48 & 1.07 \\
\hline Zhuhai & 0.12 & 0.64 & 1.22 \\
\hline Foshan & 1.15 & 1.12 & 0.94 \\
\hline Shunde & & & \\
\hline Huizhou & 0.19 & 0.71 & 1.19 \\
\hline Dongguan & 0.17 & 1.36 & 0.98 \\
\hline Zhongshan & 0.24 & 1.55 & 0.91 \\
\hline Jiangmen & 0.53 & 1.35 & 0.94 \\
\hline Zhaoqing & 1.32 & 1.25 & 0.88 \\
\hline Other cities & 1.84 & 1.34 & 0.79 \\
\hline \multicolumn{4}{|l|}{2007} \\
\hline Guangzhou & 0.18 & 0.99 & 1.10 \\
\hline Shenzhen & 1.69 & 0.53 & 1.08 \\
\hline Zhuhai & 0.12 & 0.56 & 1.26 \\
\hline Foshan & 1.19 & 1.03 & 0.97 \\
\hline Shunde & & & \\
\hline Huizhou & 0.27 & 0.61 & 1.22 \\
\hline Dongguan & 0.26 & 1.50 & 0.91 \\
\hline Zhongshan & 0.26 & 1.43 & 0.94 \\
\hline Jiangmen & 0.57 & 1.20 & 0.98 \\
\hline Zhaoqing & 1.27 & 1.20 & 0.90 \\
\hline Other cities & 1.91 & 1.32 & 0.78 \\
\hline \multicolumn{4}{|l|}{2008} \\
\hline Guangzhou & 0.14 & 0.99 & 1.12 \\
\hline Shenzhen & 1.55 & 0.50 & 1.11 \\
\hline Zhuhai & 0.10 & 0.52 & 1.29 \\
\hline Foshan & 1.11 & 1.00 & 0.98 \\
\hline Shunde & & & \\
\hline Huizhou & 0.31 & 0.65 & 1.21 \\
\hline Dongguan & 0.29 & 1.61 & 0.87 \\
\hline Zhongshan & 0.27 & 1.43 & 0.94 \\
\hline Jiangmen & 0.54 & 1.25 & 0.97 \\
\hline Zhaoqing & 1.45 & 1.10 & 0.91 \\
\hline Other cities & 2.11 & 1.35 & 0.73 \\
\hline \multicolumn{4}{|l|}{2009} \\
\hline Guangzhou & 0.17 & 0.93 & 1.11 \\
\hline Shenzhen & 1.21 & 0.48 & 1.17 \\
\hline Zhuhai & 0.13 & 0.49 & 1.27 \\
\hline Foshan & 1.14 & 1.06 & 0.97 \\
\hline Shunde & & & \\
\hline Huizhou & 0.32 & 0.62 & 1.21 \\
\hline Dongguan & 0.33 & 1.53 & 0.88 \\
\hline Zhongshan & 0.34 & 1.39 & 0.92 \\
\hline Jiangmen & 0.68 & 1.27 & 0.93 \\
\hline Zhaoqing & 2.09 & 1.09 & 0.86 \\
\hline Other cities & 2.32 & 1.43 & 0.71 \\
\hline
\end{tabular}


Annex 2 (continued)

\begin{tabular}{|c|c|c|c|}
\hline & $\begin{array}{c}\text { Resource intensive } \\
\text { industries }\end{array}$ & $\begin{array}{c}\text { Labor intensive } \\
\text { industries }\end{array}$ & $\begin{array}{c}\text { Capital intensive } \\
\text { industries }\end{array}$ \\
\hline \multicolumn{4}{|l|}{2010} \\
\hline Guangzhou & 0.27 & 0.97 & 1.05 \\
\hline Shenzhen & 0.68 & 0.50 & 1.15 \\
\hline Zhuhai & 0.22 & 0.52 & 1.17 \\
\hline Foshan & 1.65 & 1.25 & 0.90 \\
\hline Shunde & 0.27 & 0.87 & 1.07 \\
\hline Huizhou & 0.51 & 0.70 & 1.11 \\
\hline Dongguan & 0.53 & 1.93 & 0.77 \\
\hline Zhongshan & 0.58 & 1.63 & 0.85 \\
\hline Jiangmen & 1.15 & 1.60 & 0.83 \\
\hline Zhaoging & 3.58 & 1.25 & 0.79 \\
\hline Other cities & 3.05 & 1.87 & 0.65 \\
\hline \multicolumn{4}{|l|}{2011} \\
\hline Guangzhou & 0.15 & 0.93 & 1.12 \\
\hline Shenzhen & 1.34 & 0.48 & 1.16 \\
\hline Zhuhai & 0.16 & 0.48 & 1.29 \\
\hline Foshan & 1.11 & 1.10 & 0.95 \\
\hline Shunde & 0.15 & 0.91 & 1.12 \\
\hline Huizhou & 0.40 & 0.58 & 1.22 \\
\hline Dongguan & 0.28 & 1.46 & 0.90 \\
\hline Zhongshan & 0.34 & 1.33 & 0.94 \\
\hline Jiangmen & 0.79 & 1.31 & 0.90 \\
\hline Zhaoqing & 2.59 & 0.98 & 0.84 \\
\hline Other cities & 2.31 & 1.49 & 0.67 \\
\hline \multicolumn{4}{|l|}{2012} \\
\hline Guangzhou & 0.25 & 0.95 & 1.05 \\
\hline Shenzhen & 0.78 & 0.68 & 1.11 \\
\hline Zhuhai & 0.24 & 0.50 & 1.19 \\
\hline Foshan & 1.76 & 1.23 & 0.89 \\
\hline Shunde & 0.22 & 0.88 & 1.08 \\
\hline Huizhou & 0.51 & 0.54 & 1.17 \\
\hline Dongguan & 0.38 & 1.68 & 0.83 \\
\hline Zhongshan & 0.52 & 1.51 & 0.87 \\
\hline Jiangmen & 1.25 & 1.56 & 0.82 \\
\hline Zhaoqing & 4.52 & 1.21 & 0.75 \\
\hline Other cities & 2.60 & 1.81 & 0.67 \\
\hline \multicolumn{4}{|l|}{2013} \\
\hline Guangzhou & 0.17 & 0.89 & 1.13 \\
\hline Shenzhen & 1.13 & 0.41 & 1.25 \\
\hline Zhuhai & 0.15 & 0.43 & 1.34 \\
\hline Foshan & 1.12 & 0.99 & 0.99 \\
\hline Shunde & 0.12 & 0.66 & 1.24 \\
\hline Huizhou & 0.51 & 0.53 & 1.26 \\
\hline Dongguan & 0.20 & 1.05 & 1.06 \\
\hline Zhongshan & 0.32 & 1.01 & 1.07 \\
\hline Jiangmen & 0.97 & 1.12 & 0.95 \\
\hline Zhaoqing & 2.76 & 0.94 & 0.85 \\
\hline Other cities & 1.81 & 1.33 & 0.77 \\
\hline
\end{tabular}

Data source: Guangdong Statistics Bureau, 2014. 
Annex 3 Spatial concentration (Gini Coefficient) of labor, capital and resource intensive industries in cities of the PRD and the rest of the economy in Guangdong (2006-2013)

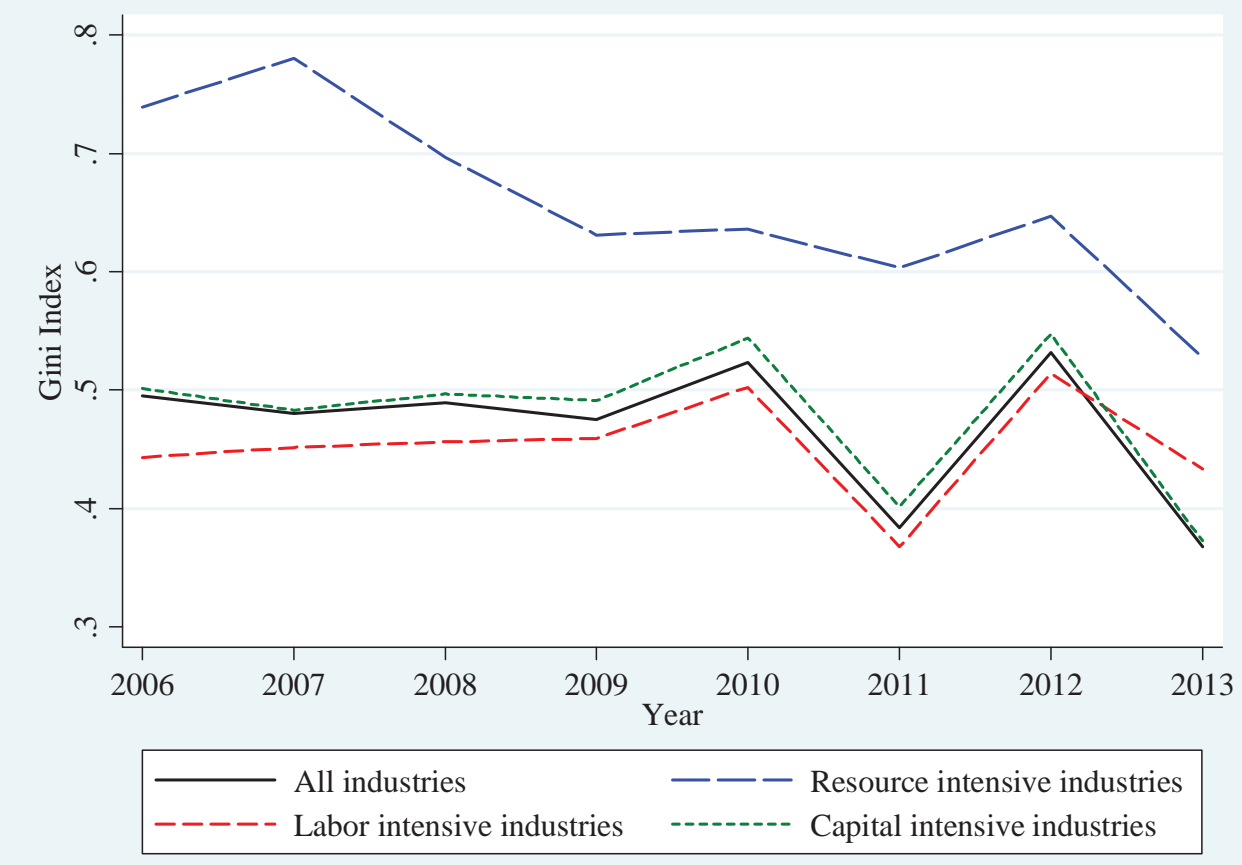

Data source: Guangdong Statistics Bureau, 2014. 